\title{
Reading Literacy of Foreign Language Students Commencing Their Tertiary Studies
}

\section{Pavla Machová, Olga Vraštilová}

\begin{abstract}
Reading is a receptive skill and together with listening it is the main source of information input. Effective mastery of reading skills thus gains more and more importance in the contemporary world deluged with information but also with the growing desire to reach the highest possible degree of education. Our experience is quite opposite though and due to it we designed a project evolving around reading competences of university applicants. It focuses on three areas: reading competence of students when commencing their tertiary studies, their reading experience since their early childhood and the requirements of the subjects and disciplines they should master during their tertiary studies. This article gives the framework of the project carried out at the Faculty of Education, University of Hradec Králové and it looks in detail into, describes and comments on the general vocabulary knowledge of the foreign language students when commencing their university studies.
\end{abstract}

Key words: literacy, competence, vocabulary. 


\title{
Čtenářská gramotnost studentů cizích jazyků na počátku jejich terciárního vzdělávání
}

\begin{abstract}
Abstrakt
Čtení jakožto receptivní řečová dovednost je spolu s poslechem hlavním vstupním kanálem informací. Efektivní zvládnutí čtenářských dovedností tak v současném světě plném informací nabývá na důležitosti. Naše zkušenost je však poněkud odlišná. Proto jsme se rozhodli navrhnout projekt, který se soustředí na čtenářské dovednosti studentů, kteří přicházejí ze střední školy na univerzitu. Ten se soustředí celkem na tři oblasti: čtenářské dovednosti studentů na počátku jejich terciárního vzdělávání, jejich čtenářskou zkušenost od dob raného dětství a potřeby a požadavky předmětů a disciplín, které by studenti měli v průběhu terciárního vzdělávání zvládnout. Tento článek rámcově pojednává o celém projektu a blíže se zaměřuje na oblast znalosti slovní zásoby studentů filologických oborů na počátku jejich univerzitního vzdělání.
\end{abstract}

Klíčová slova: gramotnost, kompetence, slovní zásoba.

\section{Problem Statement and Overview}

Research shows that reading literacy in the $21^{\text {st }}$ century has been deteriorating and together with this fact the ability of critical reading and processing written texts diminishes as well. Reading is one of the most important inputs of information for learners of any age. Being able to process written texts, distinguish relevant from irrelevant information, interpreting the message and gaining the most important facts is one of the prerequisites of university studies. Our experience shows that university applicants enter our university with underdeveloped reading skills which significantly decreases their ability to get oriented well in the academic sphere and it remains one of the fundamental problems they encounter during their tertiary studies. This situation gets even worse in the foreign language studies where students are required to process materials in a foreign language and study from them.

Our research was designed around the factors we believe influence reading competence of the university students and hence affect greatly their ability to process academic texts and gain relevant information from them.

Reading literacy has been subject to research and investigation in the past eighteen years. It is considered one of the most important competences in the contemporary rapidly developing society. More and more information overwhelm us and we are expected to process it. The major goal of education has shifted from the push for learning facts and information by heart to the ability and competence of being able to find the 
information and use it. Reading literacy thus opens doors to the worlds of various areas of our everyday lives. The PISA 2009 definition of reading literacy ("Reading literacy is understanding, using, reflecting on and engaging with written texts, in order to achieve one's goals, to develop one's knowledge and potential, and to participate in society." (PISA, 2009, p. 23)) clearly proposes that reading literacy is fundamental not only within the educational framework but it is cardinal for any other field of interest within the society. "... reading skills are essential to the academic achievement of middle- and high-school students." (Holloway, 1999 in PISA, 2009, p. 21) Receptive skills are sources of input during our education and the longer and more complex the education is, the more important the role of these skills becomes. "Reading is probably the most important skill for second language learners in academic contexts." (Grabe, 1991, p. 375) The ability to read well is considered to be the most important $L 2$ academic skill needed by students. Since the success depends very much on the ability to grasp information learned through reading the students should be able to prove various text-processing techniques-e.g., identify main ideas and details, distinguish between fact and fiction, deduce from the text, summarize, synthesize, extend textual information to further tasks, etc. (Grabe \& Stoller in Celce-Murcia, 2001, p. 189)

PISA investigates three components of the reading competence: gaining information, processing information and text evaluation. The first two components are to be found directly in the text, the third one examines also the ability to use the reader's previous experience or ability to look for connections. In the PISA 2009 report the Czech Republic was placed $27^{\text {th }}$ with the below-average score of 478 . This alarming fact was almost immediately reflected in the massive promotion of reading and reading competences within the society. Reading without the frame of school education has almost vanished and together with it the competence to process the text, gain information or find connections based on the reader's previous reading experience. Today school children do not read for pleasure very often. If they do not read in their mother tongue we cannot expect them to read in a foreign language. Then the Krashen's statement below has a rather bitter interpretation.

"Studies showing that reading enhances literacy development lead to what should be an uncontroversial conclusion: Reading is good for you. The research, however, supports a stronger conclusion: Reading is the only way, the only way we become good readers, develop a good writing style, an adequate vocabulary, advanced grammatical competence, and the only way we become good spellers." (Krashen, 2004, p. 37)

Krashen thus advocates the proposition that reading competence influences all other language skills together with spelling, vocabulary and grammar of the language.

"Vocabulary is clearly an important factor in reading, as readability studies show, but is only one of a range of factors." (Nation \& Coady, 1988 in Nation 1990, p. 116) According to Nation, learners should have a vocabulary of at least 3000 headwords to be able to read unsimplified texts. Many learners who want to carry on with their studies to 
the tertiary level may have less than this. (1990, p. 119) Nation thus suggests improving the situation by: a) learning vocabulary by direct study; b) learning vocabulary through reading (1990, p. 119)

"Vocabulary is an essential component of any language, and thus it is a critical part of second language (L2) acquisition (e.g. Nation, 2013; Willis \& Ohashi, 2012). Vocabulary knowledge influences both productive skills (speaking and writing) and receptive skills (reading and listening), and is considered a key predictor of general language proficiency (Alderson, 2007); Laufer \& Goldstein, 2004). L2 learners often acknowledge that the lack of or poor vocabulary knowledge is the main reason for their difficulties in acquiring, comprehending, and using a L2 (Nation, 2013)" (González-Fernández \& Schmitt, 2017, p. 280)

"Vocabulary is an essential aspect of language, but in many L2 classroom contexts, not much time is allocated to vocabulary teaching and learning. This lack of attention to vocabulary is a problem, because as Laufer and Nation (2011) point out, learning vocabulary entails the acquisition of thousands of items with many different aspects per item, and requires multiple encounters and considerable time." (González-Fernández \& Schmitt, 2017, p. 287)

Graves distinguishes between incidental and intentional vocabulary learning. "Incidental vocabulary learning refers to the process of acquiring vocabulary knowledge when the specific lexical item being learned is not the main focus of either the teaching or learning activity (Ender, 2016)." (González-Fernández \& Schmitt, 2017, p. 288) It is obvious that a big source of incidentally acquired vocabulary is extensive reading. A key issue is the number of exposures necessary to learn vocabulary incidentally from context. There is no agreement among the researches about the number of these encounters-Schmitt (2008) posits that eight to ten exposures are sufficient however some other researchers suggest that as few as three encounters are enough for successful acquisition of the meaning of a word (Reynolds, Wu, Liu, Kuo \& Yen, 2015). Little research has been carried out on incidental learning from listening as the second receptive skill. (González-Fernández \& Schmitt, 2017, p. 288)

"In order to ensure this repeated contact with words, teachers need to find ways to increase students' $L 2$ exposure inside and outside the classroom, and one of the most common ways of doing this is by extensive reading, which is considered a very positive way of increasing and improving learners' L2 vocabulary (Uden, Schmitt \& Schmitt, 2014)." (González-Fernández \& Schmitt, 2017, p. 289)

These findings bring us back to the initial premise of our research. Reading competence is closely connected with vocabulary knowledge and vocabulary knowledge is connected with extensive reading. 


\section{Research Framework and Rationale}

Long-term experience with the English language level of the applicants of EFL studies at our faculty indicates that with compulsory foreign language education in our schools shifted to earlier years (from the $4^{\text {th }}$ grade (age 9) to the $3^{\text {rd }}$ (age 8); at many elementary schools optional language education begins as early as in the $1^{\text {st }}$ or $2^{\text {nd }}$ grades (ages 6 or 7)) paradoxically the language level of the learners does not rise. On the contrary it decreases. With the time our first-year students have more difficulties with a smooth transfer from their secondary schools to academic education. We were wondering what reasons may be behind this unfavourable situation-unfavourable both for the undergraduates and for us, their university lecturers. We decided to look closer into the situation and we designed a project that, as we believe, may answer some of our questions. Our project focused on three areas: reading competences of our students when commencing their tertiary studies, their reading experience since their early childhood and the requirements of the subjects and disciplines they should master during their tertiary studies.

Reading competences of our first-year students were examined through a standardized reading test taken from Cambridge First Certificate in English. Males reached better scores in the reading test than females ( $\mathrm{M}-84.14 \%$ in the first test part, $\mathrm{F}-67.71 \%$; $\mathrm{M}-75.53 \%$ in the second part, $\mathrm{F}-68.40 \%$ ). (For more detailed information of this part of the research please see Machová, Vraštilová in Hradec Králové Journal of Anglophone Studies, 2017, vol. 4, No. 1, pp. 113-122).

Reading experience of these students was enquired by a questionnaire designed and piloted for this purpose. Altogether 65 questions were posed and 67 students participated. Eleven questionnaires were incomplete or illegible and therefore not considered for evaluation. The survey is therefore based on 57 respondents out of which $43(75 \%)$ were females and $14(25 \%)$ males. Altogether $91 \%$ of the students stated that they were read to by their parents or siblings when they were young and out of this number almost $56 \%$ believe that having been read to in their early childhood influenced positively their attitudes to reading, improved their vocabulary and their reading as such. The total of books read within one year differs significantly. The most frequently occurring answer of the respondents regarding their elementary school reading was between $4-5$ books per year ( 22 cases). At secondary school the highest frequency is 7 and more books and is represented by 24 respondents. Here we can induce a strong influence of the maturita exam that may influence number of books read within one year. The beginning of the students' tertiary education represents 7 and more books read with the highest frequency -20 respondents. Lower numbers of books read are represented quite equally (between 9 and 14 respondents). Interestingly there is one respondent declaring that (s)he has not read a single book within a year. This field is 
to go into more details and will be published as a separate article focusing on this particular problem area.

The requirements of the subjects and disciplines our students should master during their tertiary studies were investigated at departments educating these students. Vocabulary required for better understanding of the field of study which from the point of view of the teachers might cause problems was divided into two general sections-common vocabulary and specialist vocabulary linked to theoretical studies. The first group of words was represented by, e.g., currency (B1 level of the CEFR), effort (B1), feature (B2), survey (B2), initial (B1-B2), distinguish (B2), etc. The second group of problem words was represented by the terms like burial (C2), root (B2-C1) or vowel (B1). From the examples given we can judge that problem vocabulary from the common section belongs to B1-B2 groups of the CEFR which means that it does not exceed the borderlines of expected vocabulary knowledge of the applicants/first-year students but it still causes problems in comprehension. On the contrary specialist vocabulary ranges from $\mathrm{B} 1$ to even $\mathrm{C} 2$ groups of CEFR. This indicates that this problem vocabulary is unknown to our applicants/first-year students and should be dealt with somehow before it is actually used in particular academic disciplines where it is required both for the reception and for the production of the students.

To obtain a starting point for the third area of our research project we looked closer into the vocabulary knowledge of our applicants. Therefore we decided to analyse the vocabulary-focused part of our entrance examination tests. We were lead by the assumption that vocabulary knowledge is essential for the reading-comprehension process (e.g., Nation 1990) and therefore the knowledge of vocabulary at an appropriate level at the beginning of tertiary studies is crucial for the smooth and successful transition of the secondary-school students into their tertiary studies.

Our entrance examination test consists of four parts focusing on grammar, vocabulary, find-the-mistake exercise and British/American studies and culture.

The vocabulary part was examined in three consecutive years (2014-2016) and the results were compared. Number of applicants, proportion of males and females and best and worst performances with respect to the sex were put into graphs and charts.

The following graphs show the proportion of males and females at entrance exams for a 5year TESOL programme, and their average results. 


\section{Graph 1}

Entrance Exams - Applicant Numbers

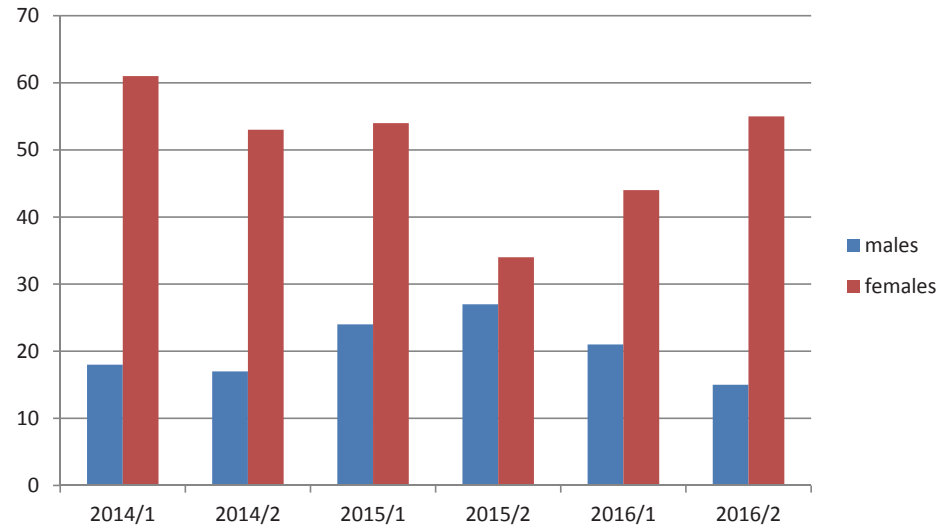

The graph shows the numbers of applicants in six entrance exams. As is apparent female applicants always outnumber the male ones which is not surprising. It is common knowledge that in the teaching profession female teachers have prevailed in the modern history of our schooling system.

Graph 2 shows the average results at entrance exams within the same time period.

\section{Graph 2}

Entrance Exams-Average Points

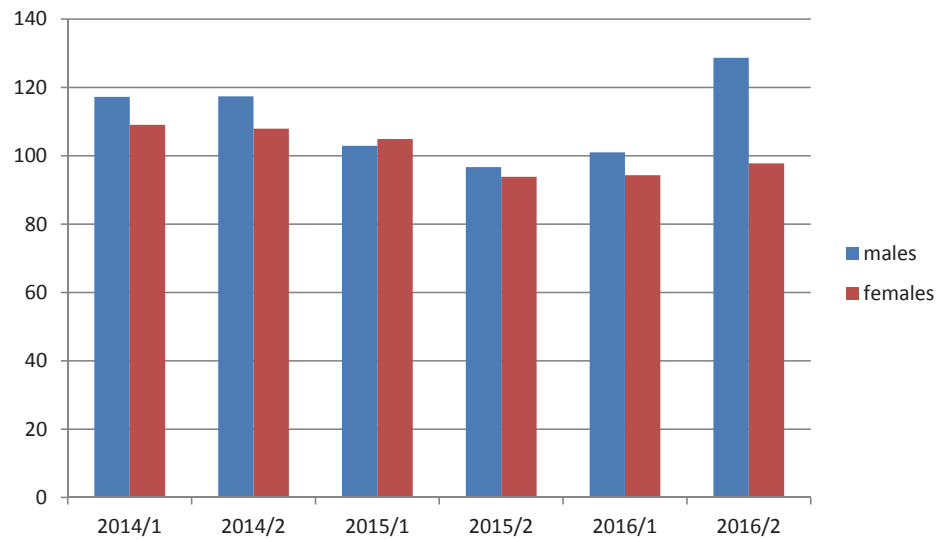


As the graph shows the average results at entrance exams have a tendency to rather decrease with time with the exception of 2016/2 test. This particular result is quite interesting since the tests are of the same format and difficulty and the difference between individual tests is usually just a few days. The details of individual test results follow in Chart 1.

\section{Chart 1}

\begin{tabular}{|l|c|c|c|c|c|c|}
\hline YEAR & $2014 / 1$ & $2014 / 2$ & $2015 / 1$ & $2015 / 2$ & $2016 / 1$ & $2016 / 2$ \\
\hline $\begin{array}{l}\text { Males number / } \\
\text { average points }\end{array}$ & $18 / 117.22$ & $17 / 117.41$ & $24 / 102.92$ & $27 / 96.70$ & $21 / 101$ & $15 / 128.67$ \\
\hline $\begin{array}{l}\text { Females number } / \\
\text { average points }\end{array}$ & $61 / 109.08$ & $53 / 107.94$ & $54 / 104.89$ & $34 / 93.85$ & $44 / 94.31$ & $55 / 97.76$ \\
\hline
\end{tabular}

The numbers of average points are in the majority of cases lower for females; the last round of 2016 hopefully shows the beginning of an upturning trend although for females the number is still very low-the pass mark for successful test completion is 120 points (out of 200).

Interestingly, in almost all respective rounds female scored both the highest and lowest numbers of points:

\section{Chart 2}

\begin{tabular}{|l|c|c|c|c|c|c|}
\hline YEAR & 2014 & 2014 & 2015 & 2015 & 2016 & 2016 \\
\hline Highest number & $185 \mathrm{~F}$ & $194 \mathrm{~F}$ & $175 \mathrm{~F}$ & $182 \mathrm{~F}$ & $1591 \mathrm{~F}+1 \mathrm{M}$ & $166 \mathrm{M}$ \\
\hline Lowest number & $39 \mathrm{~F}$ & $14 \mathrm{~F}$ & $36 \mathrm{~F}$ & $34 \mathrm{M}$ & $35 \mathrm{~F}$ & $48 \mathrm{~F}$ \\
\hline
\end{tabular}

This particular entrance exam part is a multiple-choice test where applicants are to mark their choice out of four possibilities for thirty sentences in a vocabulary oriented exercise. Having analysed this part of the tests we can say that the applicants seem to have difficulties with general vocabulary one would think should be well known by the time they successfully complete secondary school education. Surprisingly, there are even words like remember and remind, capable and suitable, etc. that cause problems (in the examples below the correct answer is given in bold, each of the answers is followed by the percentage for individual choices scored in one round of the test): 
1. His new flat of two small rooms.
a) consists $80 \%$
b) contains $5.71 \%$
c) includes $11.43 \%$
d) numbers $2.86 \%$

2. The patient had to a rest after that long walk.
a) lay $4.28 \%$
b) make $11.43 \%$
c) sleep $1.43 \%$
d) take $82.86 \%$

3. They found some squatters living in their house so they asked the court for a speedy
a) discharge $5.71 \%$
b) attainment $20 \%$
c) eviction $42.87 \%$
d) excerption $27.14 \%$ (not marked answer $4.28 \%$ )

4. You should stick this that says "Fragile" on your parcel.
a) advice $10 \%$
b) advertisement $17.14 \%$
c) label $40 \%$
d) $\operatorname{sign} 31.43 \%$ (not marked answer $1.43 \%$ )

5. I would love to go to the exhibition with them but I am afraid I cannot the time.
a) leave $5.71 \%$
b) loose $62.86 \%$
c) sale $0 \%$
d) spare $31.43 \%$

6. She has gone to the baker's to buy a of bread.
a) bar $5.71 \%$
b) bit $4.28 \%$
c) loaf $87.15 \%$
d) pound $1.43 \%$
(not marked answer 1.43\%)

7. You should not hack the off trees because they might die.
a) bark $35.71 \%$
b) bit $32.86 \%$
c) loaf $21.43 \%$
d) rind $8.57 \%$ (not marked answer 1.43\%)

8. The new house in a beautiful spot deep in the woods.
a) placed $14.29 \%$
b) rested $1.43 \%$
c) situated 32.86
d) stood $51.42 \%$

9. There was an interesting of the film in the paper last week.
a) comment $14.29 \%$
b) resume $14.29 \%$
c) revision $5.71 \%$
d) review $65.71 \%$

10. Tom turned up his to protect his neck from the cold wind.
a) cap $4.29 \%$
b) collar $55.71 \%$
c) scarf $34.28 \%$
d) sleeve $4.29 \%$ (not marked answer 1.43\%)

11. Sorry to you, but have you go the keys to the storeroom?
a) see $2.86 \%$
b) bother $84.29 \%$
c) apologize $4.29 \%$
d) excuse $8.56 \%$ 
12. We advise the visitors to our museum to advantage of our family tickets.
a) get $31.42 \%$
b) have $2.86 \%$
c) make $4.29 \%$
d) take $60.0 \%$

(not marked answer $1.43 \%$ )

13. Last month's trade figures were bad, but the ones are even worse.
a) current $62.85 \%$
b) instant $4.29 \%$
c) latter $11.43 \%$
d) newer $21.43 \%$

14. The attic of the old building was thick with as nobody had cleared it for years.
a) dust $82.85 \%$
b) powder $1.43 \%$
c) rust $4.29 \%$
d) sediment $10.0 \%$ (not marked answer $1.43 \%$ )

15. Where do you your pencils? In that drawer?
a) close $4.29 \%$
b) guard $7.14 \%$
c) hold $10.0 \%$
d) keep $78.57 \%$

\section{Graph 3}

The Proportion of Correct Answers
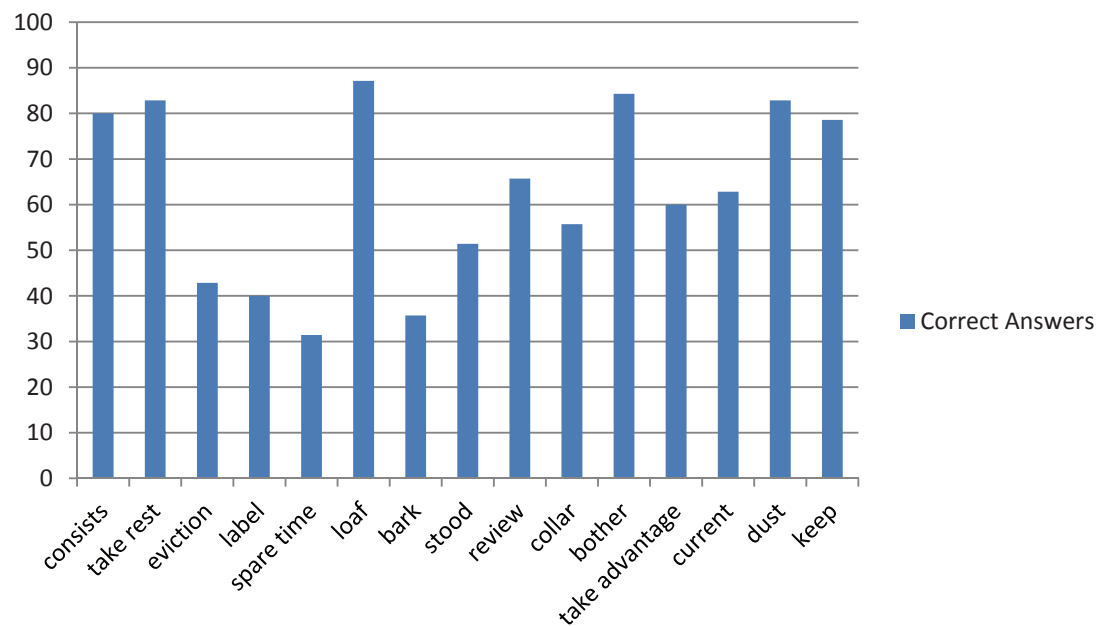

As seen from the graph, the proportion of correct answers differs. According to the CEFR (from the English Vocabulary Profile web site) the correct words belong to the levels between $\mathrm{A} 2$ and $\mathrm{C} 2$ (consist- B1, take rest - B1, eviction - C2, label- B1, spare time - A2, loaf - B2, bark - C2, stand/stood - A2, review - B1, collar - B1, bother - A2, take advantage-B1, current-B2, dust-B1, keep-A2). As apparent from the outlined levels of the 
correct answers, there are a few challenging sentences with correct answers exceeding the expected language level of the applicants (eviction, loaf, bark and current). Though they exceed the B1+ level, they have quite a good proportion of answers-eviction $42.87 \%$, loaf $-87.15 \%$, bark $-35.71 \%$ and current $-62.85 \%$. None of them belongs to the lowest number of correct answers registered in the sample of the test (spare time $31.43 \%$ or label - $40 \%$ ). Words belonging to A2 level are used correctly from $31.43 \%$ (spare time) to $84.29 \%$ (bother). Words belonging to B2 level are used correctly from $52.85 \%$ (current) to even $87.15 \%$ (loaf). Words belonging to C2 level are used correctly from $35.71 \%$ (bark) to $42.87 \%$ (eviction). These data indicate that even the words from the lowest levels can be used correctly from quite a low number of cases $(31.43 \%$ of spare time or $40 \%$ of label) to the second highest proportion of answers (bother $84.29 \%$ ). Words belonging to B1 group do not have a balanced representation either. They range from $40 \%$ of label to $82.86 \%$ of take rest. B2 to C2 words are used correctly from $35.71 \%$ (bark) to $87.15 \%$ (loaf) of cases.

These findings lead us to the conclusion that the vocabulary knowledge of our applicants is not balanced which, in our opinion, is closely connected with the data of PISA research (above) and declining reading literacy in the society.

\section{Ideas for Further Practice, Reflection}

With respect to the literature survey above the findings of our research posit a link between reading competence and the vocabulary knowledge of the secondary schoolleaving students. “... a vocabulary of at least 3000 headwords is needed to read unsimplified texts with any ease. Even with 3000 headwords, around 5 or 6 percent of the words on each page (about 15-18 words) will be unknown. Guessing is possible at this density, but the vocabulary load is still high. Developing a large reading vocabulary as quickly as possible is a very important priority for learners who wish to pursue academic study in English." (Nation, 1990, p. 116) Our suggestions to improve the current situation are as follows:

1. More reading should be employed in the ELT process at secondary schools. Students should be exposed to both simplified and unsimplified texts of various topics. CLIL may be one of the ways that could lead to the improvement of reading and increase of vocabulary of secondary school students. In this way more lexical items are acquired and reinforced through incidental vocabulary learning and further encountering of these items in the texts.

2. Each specialist discipline at the tertiary level of studies should have either its own glossary of words that are essential for understanding of the discipline and its issues, which students should master by a given time, or an introductory course of key terminology crucial and indispensable for understanding of the particular field 
of study, e.g. at the beginning of the semester. Alternatively own study materials of the particular institution can be equipped with a glossary at each chapter to reduce the load of new terminology.

3. A dictionary for related fields of study (e.g., philology) could be created by the institution with multi-lingual equivalents of essential terms for individual disciplines/ subjects of the tertiary study.

The findings of the vocabulary test analysis also propose that formulation of a multiplechoice vocabulary test is a very responsible and demanding task especially with respect to the selection of words and contexts of the proper language level.

\section{References}

González-Fernandéz, B., Schmitt, N. (2017). Vocabulary Acquisition. In S. Loewen \& M. Sato (eds), The Routledge Handbook of Instructed Second Language Acquisition (pp. 280-298). New York: Routledge.

Grabe, W. (1991). Current developments in second language reading research. TESOL quarterly, 25(3), (pp. 375-406).

Grabe, W. \& Stoller, F. L. (2001). Reading for academic purposes: Guidelines for the ESL/EFL teacher. In M. Celce-Murcia (ed.) Teaching English as a second or foreign language, 3 (pp. 187-203). Boston, MA: Heinle Cengage Learning.

Krashen, S. D. (2004). The Power of Reading. Insights from the Research. Portsmouth: Heinemann. Nation, I. S. P. (1990). Teaching \& Learning Vocabulary. Boston, MA: Heinle \& Heinle Publishers. PISA 2009 Assessment Framework. Key competencies in reading, mathematics and science. OECD.

\section{Contact:}

Mgr. Olga Vraštilová, M.A., Ph.D.

Mgr. Pavla Machová, M.A., Ph.D.

Katedra anglického jazyka a literatury

Pedagogická fakulta, Univerzita Hradec Králové

Rokitanského 62, 50003 Hradec Králové, Czech Republic

E-mails: Olga.Vrastilova@uhk.cz; Pavla.Machova@uhk.cz

Olga Vraštilová is a Lecturer at the Department of English Language and Literature, Pedagogical Faculty, University of Hradec Králové. She is a primary a lower-secondary school teacher trainer and she is a methodology teacher in these study programmes. Within her work she focuses, among other issues, on using children's literature in ELT and CLIL.

Pavla Machová is a Lecturer at the Department of English Language and Literature, Pedagogical Faculty, University of Hradec Králové. She is a teacher trainer, mostly concentrating on ELT methodology. She focuses on specific learning disabilities, reading literacy and teaching English to students with hearing impairments. While lecturing she also applies the experience from ELT at a local secondary school for students with various disabilities. 